\title{
Leukotriene receptor antagonists and related compounds
}

\author{
Sally E Wenzel MD \\ National Jewish Medical and Research Center, Denver, Colorado, USA
}

\section{SE Wenzel. Leukotriene receptor antagonists and related compounds. Can Respir J 1999;6(2):189-193.}

Leukotrienes (LTs), lipid mediators of inflammation, have proved to be important biochemicals involved in the symptoms and physiological changes of asthma. In the past year and a half, the development of three new drugs that modulate the LT pathway has been completed. The first subclass of these drugs, leukotriene receptor antagonists (LTRA) (zafirlukast and montelukast), blocks the interaction of the cysteinyl form of the LTs with the cell type bearing the receptor. The second subclass, the 5-lipoxygenase (5-LO) inhibitors (zileuton) inhibits the 5-LO enzyme, which prevents the formation of both cysteinyl LTs and LTB4. The LT modulators have shown efficacy in inhibiting the physiological changes occurring after allergen, acetylsalicylic acid and exercise challenge in asthmatics. In addition, they have shown efficacy in improving symptoms, beta-agonist use and forced expiratory volume in $1 \mathrm{~s}\left(\mathrm{FEV}_{1}\right)$ in chronic, 'day-to-day' asthma in patients with mild disease. Comparison studies with low doses of inhaled corticosteroids suggest that LT modulators may have similar effects on symptom scores and beta-agonist use, but have lesser effects on FEV 1 . Finally, emerging data suggest that these drugs are beneficial in decreasing the dose of inhaled corticosteroids necessary to control more moderate to severe asthma. While long term studies will be helpful in determining the 'disease modifying' effects of these drugs, data suggest that these drugs are useful in the treatment of a broad range of asthmatic patients.

Key Words: 5-lipoxygenase inhibitors, Inflammation, Inhaled corticosteroids, Leukotriene receptor antagonists

\section{Antagonistes des récepteurs des leucotriènes et composés associés}

RÉSUMÉ : Les leucotriènes (LT), médiateurs lipidiques de l'inflammation, ont prouvé qu'ils sont d'importants agents biochimiques impliqués dans les symptômes et les changements physiologiques de l'asthme. Au cours des dix huit derniers mois, trois nouveaux médicaments qui modulent la voie des leucotriènes ont été mis au point. La première sous-classe de ces médicaments, les antagonistes des récepteurs des leucotriènes (ARLT) (zafirlukast et montélukast), bloquent l'interaction des leucotriènes à groupe cystéinyle avec le type de cellule contenant le récepteur. La deuxième sous-classe, les inhibiteurs de la 5-lipoxygénase (zileuton), inhibent l'enzyme 5-LO, qui prévient la formation à la fois des LT cystéiniques et des LT B4. Les modulateurs des LT ont démontré leur efficacité pour inhiber les changements physiologiques qui surviennent après une épreuve d'effort, un test de provocation à l'aspirine ou aux allergènes chez les asthmatiques. De plus, ils contribuent à l'amélioration des symptômes, à réduire l'utilisation des bêta-agonistes et à augmenter le VEMS chez les patients atteints d'asthme chronique mais léger. Des études comparatives avec des doses faibles de corticostéroïdes en inhalation permettent de croire que les modulateurs des LT ont des effets similaires sur les scores des symptômes et de l'utilisation des bêta-agonistes, mais des effets moindres sur le VEMS. Finalement, des données émergentes permettent de croire que ces médicaments auraient un effet bénéfique concernant la réduction de la dose de corticostéroïdes nécessaire pour maîtriser l'asthme modéré à grave. Des études à long terme seront nécessaires pour déterminer les effets «modificateurs de la maladie » de ces agents, mais les données laissent à penser que ces médicaments sont utiles pour traiter une grande variété de patients asthmatiques. 
$\mathbf{I}_{\mathrm{s}}^{\mathrm{n}}$ nflammation is a significant contributing factor to the symptoms and physiological changes of asthma. Activation of the arachidonic acid cascade leads to production of lipid mediators known as leukotrienes (LTs), important components of this inflammatory process. In the past 18 months, new drugs have become available that were specifically developed to interfere with that pathway, namely, LT receptor antagonists (LTRAs) and 5-lipoxygenase (5-LO) inhibitors. This is the first time that such 'designer drugs' have become available as a new option to manage chronic asthma.

\section{THE LT PATHWAY}

LTs are potent lipid mediators that have long been implicated in the pathogenesis of asthma (Figure 1). They are endproducts of the metabolism of arachidonic acid, formed from phospholipids, which are ubiquitous elements of cellular membranes. Arachidonic acid is formed from phospholipids through enzymatic activation of various phospholipases and can then be further metabolized by a variety of pathways. These include the cyclo-oxygenase pathway, which leads to production of prostaglandins and thromboxane (and is inhibited by acetylsalicylic acid (ASA) and other nonsteroidal anti-inflammatory compounds), and the 5-LO pathway, which leads to the production of LTs (1). Activation of 5-LO is thought to require generalized cellular activation and the availability of arachidonic acid as substrate. It is presumed to require interactions with a protein known as 5-LO activating protein, which is thought to channel arachidonic acid to the enzyme 5-LO. 5-LO activation then leads to the production of an intermediate known as LTA4, which can be further metabolized, depending on cell type, to LTB4 or the cysteinyl LTs, LTC4, D4 and E4 (formerly known as slow-reacting substance of anaphylaxis).

LTs are produced almost exclusively by cells of the myeloid lineage. LTB4 is a potent chemoattractant for neutrophils and eosinophils, as well as an activator of neutrophils, which appears to enhance adhesion and migration of the cells through the endothelium (2). Cysteinyl LTs are potent bronchoconstrictors (100 to 1000 times more potent than histamine) that enhance membrane permeability and decrease mucociliary clearance (2). In addition, LTE4 has recently been shown to have chemoattractant properties for eosinophils in the lungs of asthmatics (3). Both cysteinyl LTs and LTB4 have been measured in the airways of asthmatics $(4,5)$. Cysteinyl LTs in humans appear to activate cells predominantly through a single receptor, known as the cystLT1 receptor, although the exact structure of the receptor and whether other receptor types may exist remain elusive (1). LTB4 functions solely through the LTB4 receptor, which was recently cloned (6).

Modulation of LT activity has centered on two components of the pathway (Table 1). Both antagonists of the LT receptor and inhibitors of 5-LO have undergone large scale clinical trials. The chief biological difference between the LTRAs and the 5-LO inhibitors is that LTRAs inhibit the activity of the cysteinyl LTs only, while 5-LO inhibitors block the production of both LTB4 and the cysteinyl LTs, but

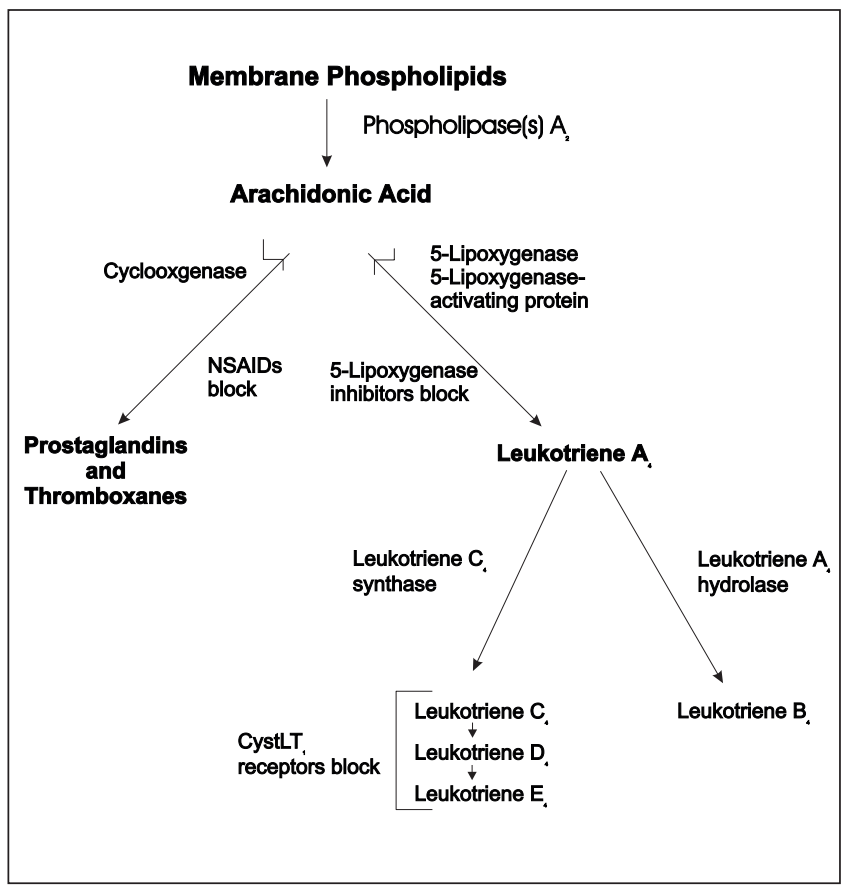

Figure 1) The arachidonic acid cascade. cystLT Cysteinyl leukotriene receptor; NSAID Nonsteroidal anti-inflammatory drug

\section{TABLE 1}

Leukotriene (LT) antagonists and pathway inhibitors

\begin{tabular}{lc}
\hline Receptor antagonists & Pathway inhibitors \\
Block the actions of & Block the production of LTB4 \\
cysteinyl LTs & and cysteinyl LTs \\
zafirlukast (Accolate, & zileuton (Zyflo, Abbott \\
Zeneca Pharma Inc) & Pharmaceuticals, USA) \\
montelukast (Singulair, & \\
Merck Frosst Canada Inc) & \\
pranlukast (Ultair, Onon Ono & \\
Pharmaceuticals, Japan) & \\
\hline
\end{tabular}

whether this difference has clinical applications for asthma therapy remains unclear. LTRAs and 5-LO inhibitors have been studied in both laboratory-induced asthma, such as allergen challenge, and in 'day-to- day' or 'chronic' asthma. These agents have largely been studied in mild to moderate asthmatics, but data from more severe patients are emerging as well.

\section{EFFICACY IN LABORATORY ASTHMA (CHALLENGE AND BRONCHOSCOPIC STUDIES)}

In recent years, LTRAs have been developed that shift the dose response to inhaled LTD4 30- to 100-fold, indicating almost complete blockade of the LT receptor (7). It is not possible to evaluate 5-LO inhibitors in this same way. In addition, LT modulators effectively inhibit allergen- and ASA-induced asthma, with lesser reductions in exerciseinduced bronchoconstriction. While the inhibition of the late bronchoconstriction associated with allergen challenge is approximately $50 \%$, the early phase of bronchoconstriction, 
which is thought to be predominantly mast cell driven, is almost completely abolished $(8,9)$. In addition to the improvement in obstruction, the LTRA zafirlukast (Accolate, Zeneca Pharma) has demonstrated a small but significant ability to limit the increase in airway reactivity, which normally occurs after allergen exposure.

Bronchoconstriction associated with ASA challenge has also been nearly completely prevented by LTRAs and 5-LO inhibitors, confirming the importance of LTs in the bronchospasm associated with the ASA reaction (10-12). Recently, longer term studies of ASA-sensitive asthmatics support the efficacy of chronic dosing in this population as well $(13,14)$.

The bronchoconstriction associated with exercise appears to be consistently inhibited by LTRAs in the range of $30 \%$ to $50 \%$. This inhibition appears to compare favourably to pretreatment with cromolyn (15). A long term study with montelukast (Singulair, Merck Frosst Canada Inc) demonstrated sustained protection against exercise-induced bronchospasm over the 12 weeks of the study, when montelukast was taken 16 to $18 \mathrm{~h}$ before exercise (16).

The effect of these drugs on inflammation in the airways has only been partially addressed, and no biopsy studies have yet been reported. However, preliminary work suggests that LTRAs may decrease the inflammatory cell influx into the airways after instillation of allergen and over time. Administration of zafirlukast for one week before instillation of allergen directly into the airways of asthmatics significantly decreased the influx of basophils and lymphocytes into the airways $48 \mathrm{~h}$ after allergen exposure compared with placebo. Zafirlukast tended to decrease the numbers of eosinophils migrating into the airways also (17). Montelukast has also demonstrated an effect on sputum eosinophils over time (18).

In a nocturnal asthma model, the 5-LO inhibitor, zileuton (Zyflo, Abbott Pharmaceuticals, USA), was found to decrease urinary and bronchoalveolar lavage fluid (BAL) LT levels, while improving pulmonary function in patients with nocturnal asthma (Figure 2). The improvement in function correlated with the levels of LTB4 in the airways. Additionally, the eosinophils in the BAL and peripheral blood decreased significantly, supporting a cellular-level anti-inflammatory effect (5).

\section{CHRONIC ASTHMA}

Some LT modulators can induce a rapid and significant immediate bronchodilating effect of between $15 \%$ and $30 \%$ (19). This effect has also been seen with zileuton and high doses of zafirlukast $(20,21)$. These results imply that LTs are always present in the airways of asthmatics and are playing an important role in maintaining baseline asthmatic bronchoconstriction. In addition, concomitant treatment of these individuals with a beta-agonist induces an additive effect on the bronchodilation, suggesting that the two types of compounds are working through different pathways (19).

Several long term, placebo controlled trials have been published in abstract or manuscript form with the LTRAs zafirlukast, pranlukast (Ultair, Onon-Ono Pharma, Japan) and montelukast, and the 5-LO inhibitor zileuton. Although

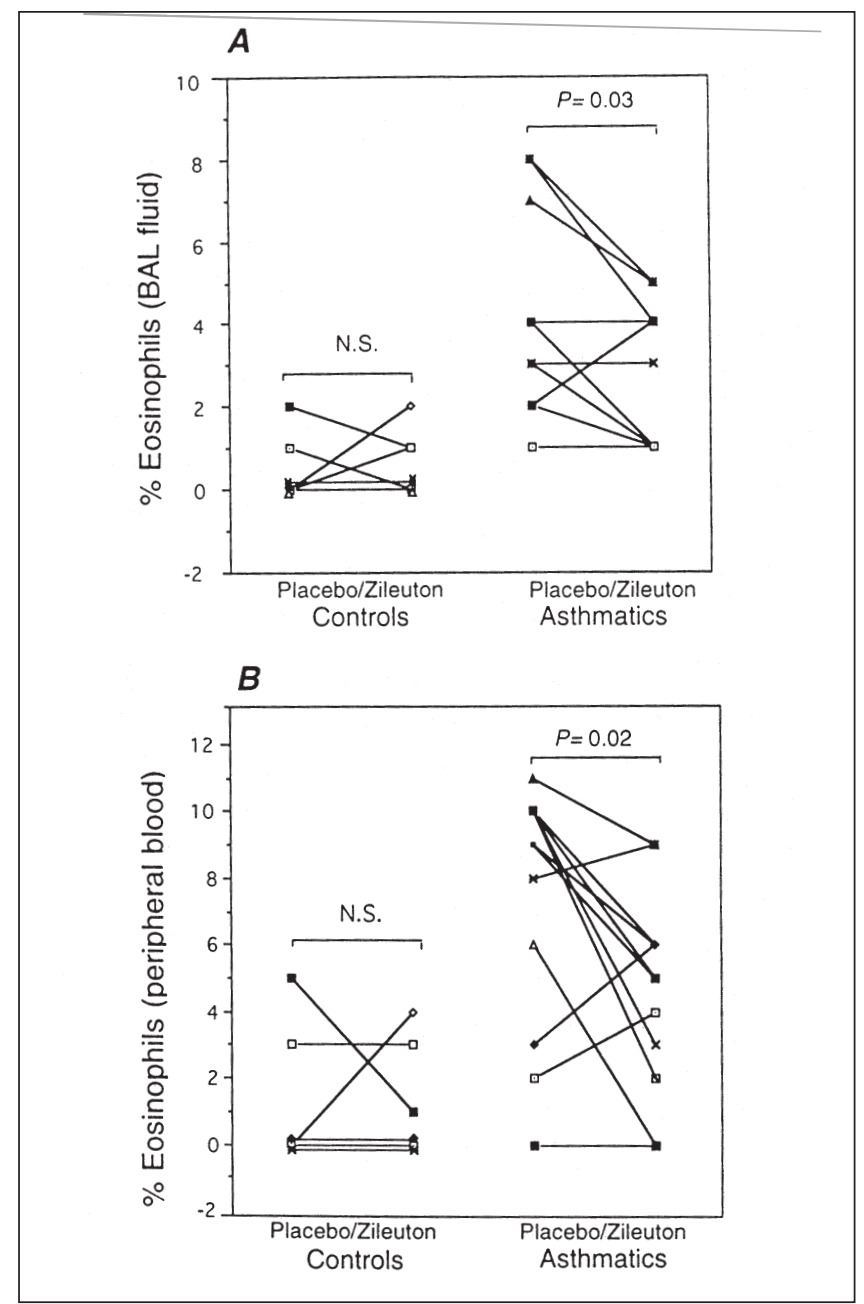

Figure 2) Zileuton significantly decreased bronchoalveolar lavage (BAL) fluid and peripheral lood eosinophils in nocturnal asthma subjects. NS Not significant

the patients studied had mild asthma as judged by forced expiratory volume in $1 \mathrm{~s}\left(\mathrm{FEV}_{1}\right)$, medication needs and symptom scores, these compounds have consistently shown both statistical and clinical efficacy in this population (20,22-24). Use of these compounds has led to sustained improvement in $\mathrm{FEV}_{1}$, symptom scores and beta-agonist use for the duration of the trial compared with placebo. Nocturnal asthma symptoms also appear to be improved by these compounds. Zafirlukast, montelukast and zileuton also significantly decreased the number of occasions on which study subjects needed a steroid burst $(24,25)$.

Studies comparing inhaled corticosteroids with zafirlukast, montelukast and pranlukast have now been carried ou with remarkably similar results. All of these studies suggest that LTRAs are not as effective as low dose beclomethasone in improving $\mathrm{FEV}_{1}$. Interestingly, however, very few differences are seen between the two types of drugs when evaluating other end-points such as and beta-agonist use $(26,27)$.

Finally, from a clinical efficacy perspective, recent studies with all of the LT-modulating drugs suggest that there are additional benefits to the use of these drugs in patients cur- 
rently treated with inhaled corticosteroids. The only study published to date demonstrated that the concomitant use of pranlukast allowed the inhaled corticosteroid dose $(1600 \mu \mathrm{g} / \mathrm{day})$ to be cut to $800 \mu \mathrm{g} /$ day in moderate asthmatics without compromising asthma control (Figure 3) (28). A similar study was done with montelukast (29). In a somewhat different approach, adding a LT drug (montelukast or zileuton) to low doses of inhaled corticosteroids was better than doubling or maintaining the dose of the inhaled steroids, similar to results of studies with salmeterol and theophylline $(30,31)$.

From a health economic perspective, there are statistically significant improvements in days missed from work and school, as well as significantly decreased rates of asthma exacerbation (23). A recent year-long study has shown that the addition of zileuton to "usual care" (inhaled steroids, theophylline, cromones) appears to reduce the need for steroid bursts, emergency room visits and hospitalizations compared with the "usual care" alone group (32).

These drugs are dosed orally anywhere from one to four times/day. This oral dosing may lead to better compliance with these medications. Zafirlukast is dosed as $20 \mathrm{mg}$ orally bid (without food), montelukast $10 \mathrm{mg}$ every evening (adults) and zileuton $600 \mathrm{mg}$ qid. An eight-week study with montelukast in children recently demonstrated safety and efficacy compared with placebo in children on no or concurrent treatment with inhaled corticosteroids at $5 \mathrm{mg} /$ day (33). The improvement in $\mathrm{FEV}_{1}$ was in the range seen in the adult studies. All the clinical trials with montelukast were done with bedtime dosing. Nothing is known regarding dosing at other times of the day.

\section{SAFETY}

In general, these drugs appear to be well tolerated. Whether some of these drugs have potential liver toxicity is not yet clear, but zileuton has a 3\% incidence of elevations in alanine aminotransferase versus placebo (24). Higher doses of zafirlukast ( $80 \mathrm{mg}$ bid) likely have a similar effect on transaminases. No effect has been seen with montelukast.

There is some suggestion that a tachyphylaxis may occur with some of these compounds, such that higher doses are needed to maintain effective protection against challenges such as exercise (34). However, this effect was not seen with montelukast (16).

Because all of these compounds are metabolized by the liver, the possibility for significant drug interactions with other drugs metabolized by the P450 enzyme system clearly exists, but many such interactions, as could occur with antiepileptic drugs, have not yet been reported. Zafirlukast (and to a smaller extent, zileuton) has considerable interaction with warfarin, such that the dose of warfarin would likely have to be cut by up to $50 \%$. Zileuton is also metabolized via the cytochrome P450 system, and recommendations for concurrent use with theophylline suggest decreasing the dose of theophylline by $50 \%$ and then checking the theophylline level. In addition, food appears to interfere with the absorption of zafirlukast, and the drug must be dosed $1 \mathrm{~h}$ before or after meals.

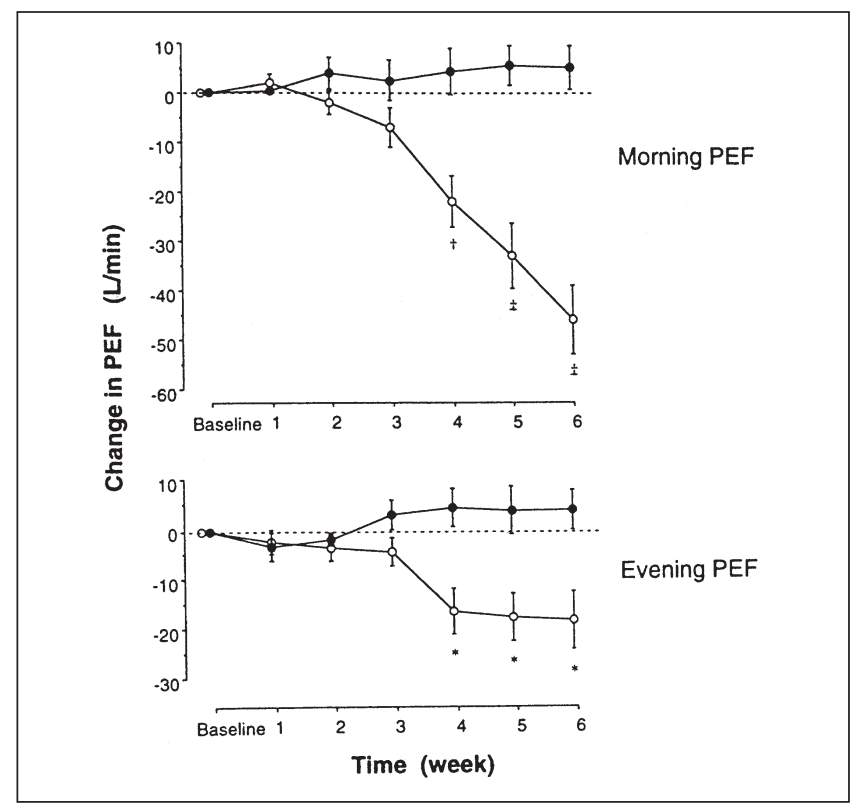

Figure 3) The leukotriene receptor antagonist pranlukast following a reduction in inhaled steriods was able to prevent reductions in peak flows significantly better than placebo. PEF Peak expiratory flow

Of perhaps the greatest concern is the possible association of zafirlukast and montelukast with Churg-Strauss syndrome, a rare eosinophilic vasculitis. Recently, eight patients treated with zafirlukast who had previously been on oral steroids were reported to present with Churg-Strauss syndrome. It is currently unclear whether this was a direct causal effect, or whether the Churg-Strauss was there previously and unmasked when the steroids were tapered. More information is needed before conclusions can definitively be drawn, but physicians should seriously consider complaints regarding new rashes or neurological or worsening respiratory symptoms (35). Whether cases will be reported with zileuton is not yet known.

\section{HOW WILL THESE COMPOUNDS BE USED IN THE TREATMENT OF ASTHMA?}

As the understanding of the long term efficacy and safety of these LT modulators improves, our ability to place these drugs into treatment guidelines will also improve. The initial evaluation of these drugs by the most recent (1997) National Asthma Education Program guidelines suggest that LTmodulating drugs may be used as an alternative to inhaled corticosteroids in the treatment of mild persistent asthma. Although this is certainly an option, patients with more severe disease may also benefit from add-on therapy to low dose inhaled corticosteroids and/or in more severely obstructed patients as an alternative to theophylline or a long-acting beta-agonist. A distinct advantage of these compounds is the oral dosing which may make compliance and adherence better, especially in the large percentage of patients who do not use their inhaled steroids regularly for any number of reasons. These drugs also promise to be very helpful in the treatment of aspirin-sensitive asthmatics. However, further 
clinical experience with the long term disease modifying effects of these drugs is necessary before their final place in asthma treatment is known.

\section{REFERENCES}

1. Henderson WR Jr. The role of leukotrienes in inflammation. Ann Intern Med 1994;121:684-97.

2. Lewis RA, Austen F, Soberman RJ. Leukotrienes and other products of the 5-lipoxygenase pathway. N Engl J Med 1990;323:645-55.

3. Laitinen LA, Laitinen A, Haahtela T, Vilkka V, Spur BW, Lee TH. Leukotriene E4 and granulocytic infiltration into asthmatic airways. Lancet 1993;341:989-90.

4. Wenzel SE, Larsen GL, Johnston K, Voelkel NF, Westcott JY. Elevated levels of leukotriene $\mathrm{C} 4$ in bronchoalveolar lavage fluid from atopic asthmatics after endobronchial allergen challenge. Am Rev Respir Dis 1990;142:112-9.

5. Wenzel S, Trudeau J, Kaminsky D, Cohn J, Martin R, Westcott J. Effect of 5-lypoxygenase inhibition on bronchocontraction and airway inflammation in nocturnal asthma. Am J Respir Crit Care Med 1995;152:897-905.

6. Yokomizo T, Izumi T, Chang K, Takuwa Y, Shimizu T. A G-protein-coupled receptor for leukotriene B4 that mediates chemotaxis. Nature 1997;387:620-4.

7. Smith LJ, Glass M, Minkwitz MC. Inhibition of leukotriene D4-induced bronchoconstriction in subjects with asthma: A concentration-effect study of ICI 204,219. Clin Pharmacol Ther 1993;54:430-6.

8. Taylor IK, O'Shaughnessy KM, Fuller RW, Dollery CT. Effect of cysteinyl-leukotriene receptor antagonist ICI 204,219 on allergen-induced bronchoconstriction and airway hyperreactivity in atopic subjects. Lancet 1991;337:690-4.

9. Findlay SR, Barden JM, Easley CB, Glass M. Effect of the oral leukotriene antagonist, ICI 204,219, on antigen-induced bronchoconstriction in subjects with asthma. J Allergy Clin Immunol 1992;89:1040-5.

10. Christie P, Smith C, Lee TH. The potent and selective sulfidopeptide leukotriene antagonist, SK\&F 104353 inhibits aspirin induced asthma. Am Rev Respir Dis 1991;144:957-8.

11. Israel E, Fischer AR, Rosenberg MA, et al. The pivotal role of 5-lipoxygenase products in the reaction of aspirin-sensitive asthmatics to aspirin. Am Rev Respir Dis 1993;148:1447-51.

12. Fischer AR, Rosenberg MA, Lilly CM, et al. Direct evidence for a role of the mast cell in the nasal response to aspirin in aspirin-sensitive asthma. J Allergy Clin Immunol 1994;94:1046-56.

13. Dahlen S, Nizankowska E, Dahlen B, et al. The Swedish-Polish treatment study with the 5-lipoxygenase inhibitor zileuton in aspirin-intolerant asthmatics. Am J Respir Crit Care Med 1995;151:376. (Abst)

14. Kuna P, Malmstrom K, Dahlen SE, et al. Montelukast (MK-0476), A CysLT1 receptor antagonist, improves asthma control in aspirin-intolerant asthmatic patients. Am J Respir Crit Care Med 1997;155:975. (Abst)

15. Robuschi M, Riva E, Fuccella L, et al. Prevention of exercise-induced bronchoconstriction by a new leukotriene antagonist (SK\&F 104353). Am Rev Respir Dis 1992;145:1285-8.

16. Leff JA, Bronsky EA, Kemp J, et al. Montelukast (MK-0476) inhibits exercise-induced bronchoconstriction (EIB) over 12-weeks without causing tolerance. Am J Respir Crit Care Med 1997;155:977. (Abst)

17. Calhoun WJ, Lavins BJ, Glass M. Effect of Accolate (zafirlukast) on bronchoalveolar lavage fluid (BAL) after segmental antigen bronchoprovocation (SBP) in patients with mild to moderate asthma. Am J Respir Crit Care Med 1995;151:42. (Abst)

18. Leff JA, Pizzichini E, Efthimiadis A, et al. Effect of montelukast (MK-0476) on airway eosinophilic inflammation in mildly uncontrolled asthma: a randomized placebo-controlled trial. Am J Respir Crit Care Med 1997;155:977. (Abst)

19. Gaddy J, Margolskee D, Bush R, Williams VC, Busse WW. Bronchodilation with a potent and selective leukotriene D4 (LTD4) receptor antagonist (MK-571) in patients with asthma. Am Rev Respir Dis 1992;146:358-63.

20. Israel E, Rubin P, Kemp J, et al. The effect of inhibition of 5-lipoxygenase by zileuton in mild-to-moderate asthma. Ann Intern Med 1993;119:1059-66.

21. Bateman ED, Aitchison JA, Summerton L, Harris A. The early onset of action of zafirlukast (Accolate) in patients with asthma. Am J Respir Crit Care Med 1997;155:Abst 663. (Abst)

22. Spector SL, Smith LJ, Glass M. Effects of 6 weeks of therapy with oral doses of ICI 204,219, a leukotriene D4 receptor antagonist, in subjects with bronchial asthma. Am J Respir Crit Care Med 1994;150:618-23.

23. Suissa S, Dennis R, Ernst P, Sheehy O, Wood-Dauphinee S. Effectiveness of the leukotriene receptor antagonist zafirlukast for mild-to-moderate asthma. A randomized, double-blind, placebo-controlled trial. Ann Intern Med 1997;126:177-83.

24. Liu MC, Dube LM, Lancaster J, Group ZS. Acute and chronic effects of a 5-lipoxygenase inhibitor in asthma: a 6-month randomized multicenter trial. J Allergy Clin Immunol 1996;98:859-71.

25. Barnes NC, Black B, Syrett N, Cohn J. Reduction of exacerbations of asthma in multinational clinical trials of zafirlukast (Accolate). Am J Respir Crit Care Med 1996;153:802. (Abst)

26. Wenzel S, Chervinsky P, Kerwin E, et al. Oral pranlukast (Ultair) vs inhaled beclomethasone: results of a 12-week trial in patients with asthma. Am J Respir Crit Care Med 1997;155:203. (Abst)

27. Singulair. Package Insert. Rahway, New Jersey: Merck Frosst Inc, 1998.

28. Tamaoki J, Kondo M, Sakai N. Leukotriene antagonist prevents exacerbation of asthma during reduction of high-dose inhaled corticosteroid. Am J Respir Crit Care Med 1997;155:1235-40.

29. Leff JA, Israel E, Noonan MJ, et al. Montelukast (MK00476) allows tapering of inhaled corticosteroids (ICS) in asthmatic patients while maintaining clinical stability. Am J Respir Crit Care Med 1997;155:976. (Abst)

30. O'Connor B, Godard P, Dube L, et al. The comparative effect of zileuton, a 5-lipoxygenase inhibitor, plus low dose inhaled beclomethasone vs higher dose beclomethasone for asthma. J Allergy Clin Immunol 1996;97(No 1 Pt 2):250. (Abst)

31. Greening AP, Ind PW, Northfield M, Shaw G. Added salmeterol versus higher-dose corticosteroid in asthma patients with symptoms on existing inhaled corticosteroid. Lancet 1994;344:219-24.

32. Lazarus SC, Lee TM, Wright S, et al. Secondary outcomes analysis of zileuton plus usual care vs usual care alone in the treatment of patients with asthma. Ann Allergy Asthma Immunol 1997;78:94.

33. Knorr B, Matz J, Berstein JA, et al. Montelukast for chronic asthma in 6- to 14-year old children: A randomized, double-blind trial. JAMA 1995;279:1181-6.

34. Adelroth E, Inman MD, Summers E, Pace D, Modi M, O'Byrne PM. Prolonged protection against exercise-induced bronchoconstriction by the leukotriene D4-receptor antagonist cinalukast. J Allergy Clin Immunol 1997;99:210-5.

35. Wechsler ME, Garpestad E, Flier SR, et al. Pulmonary infiltrates, eosinophilia, and cardiomyopathy following corticosteroid withdrawal in patients with asthma receiving zafirlukast. JAMA 1998;279:455-7. 


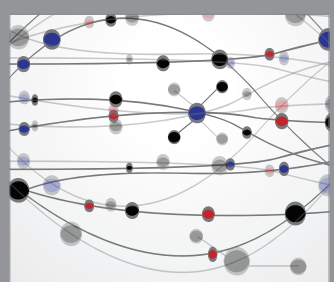

The Scientific World Journal
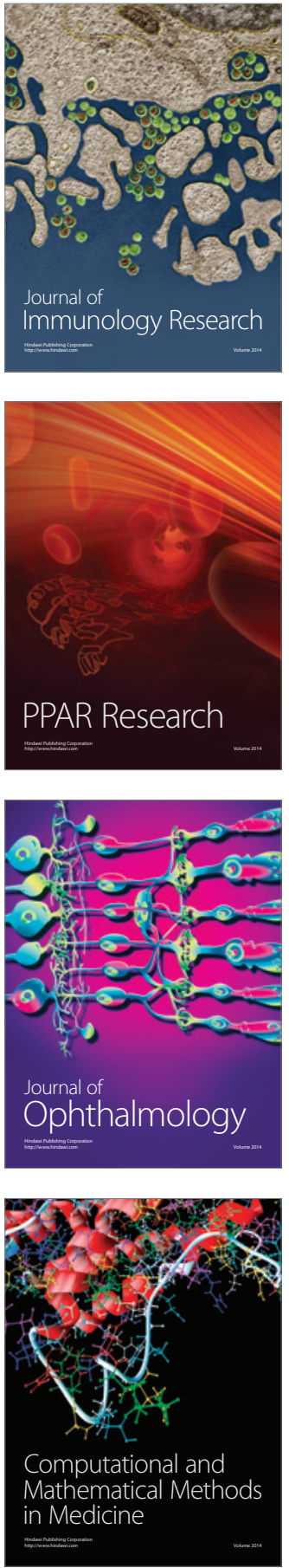

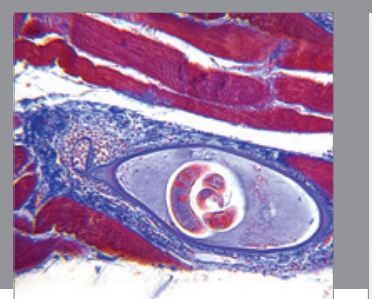

Gastroenterology Research and Practice

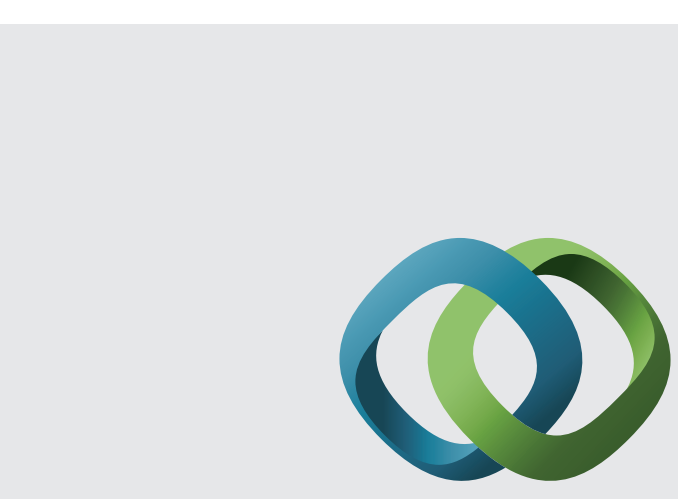

\section{Hindawi}

Submit your manuscripts at

http://www.hindawi.com
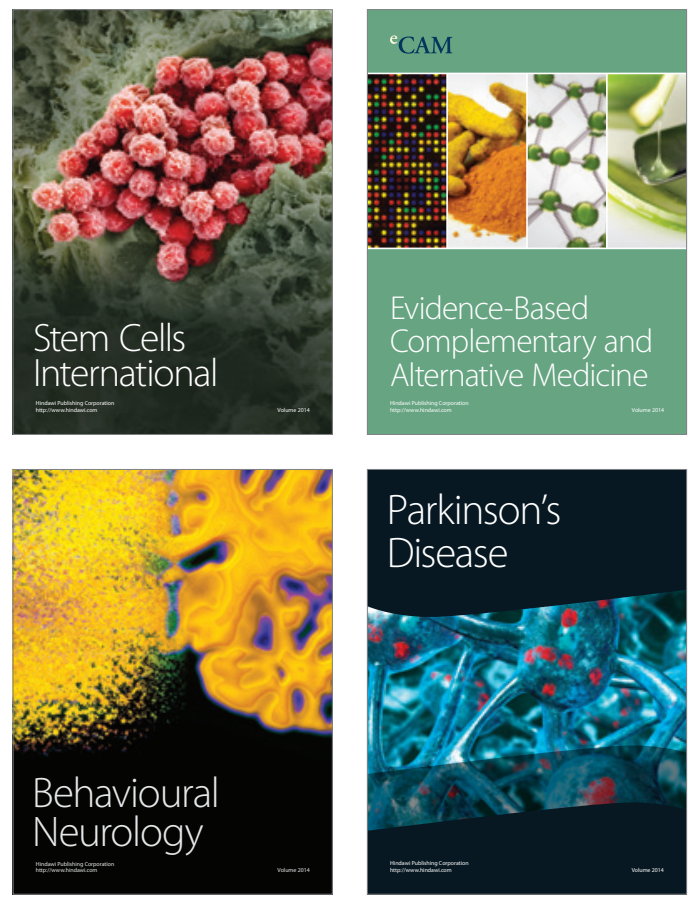
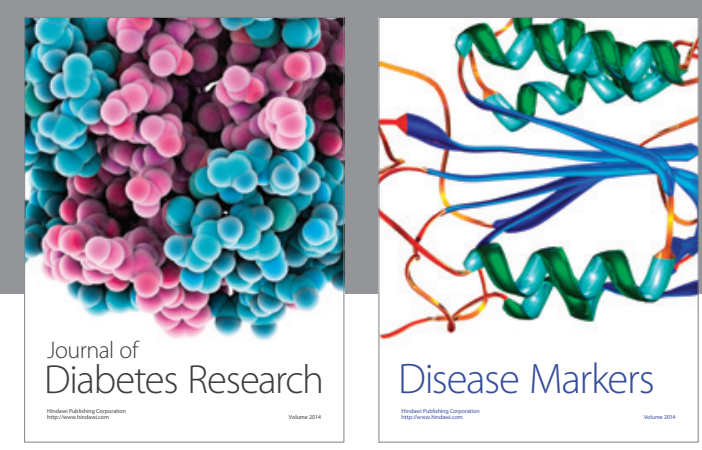

Disease Markers
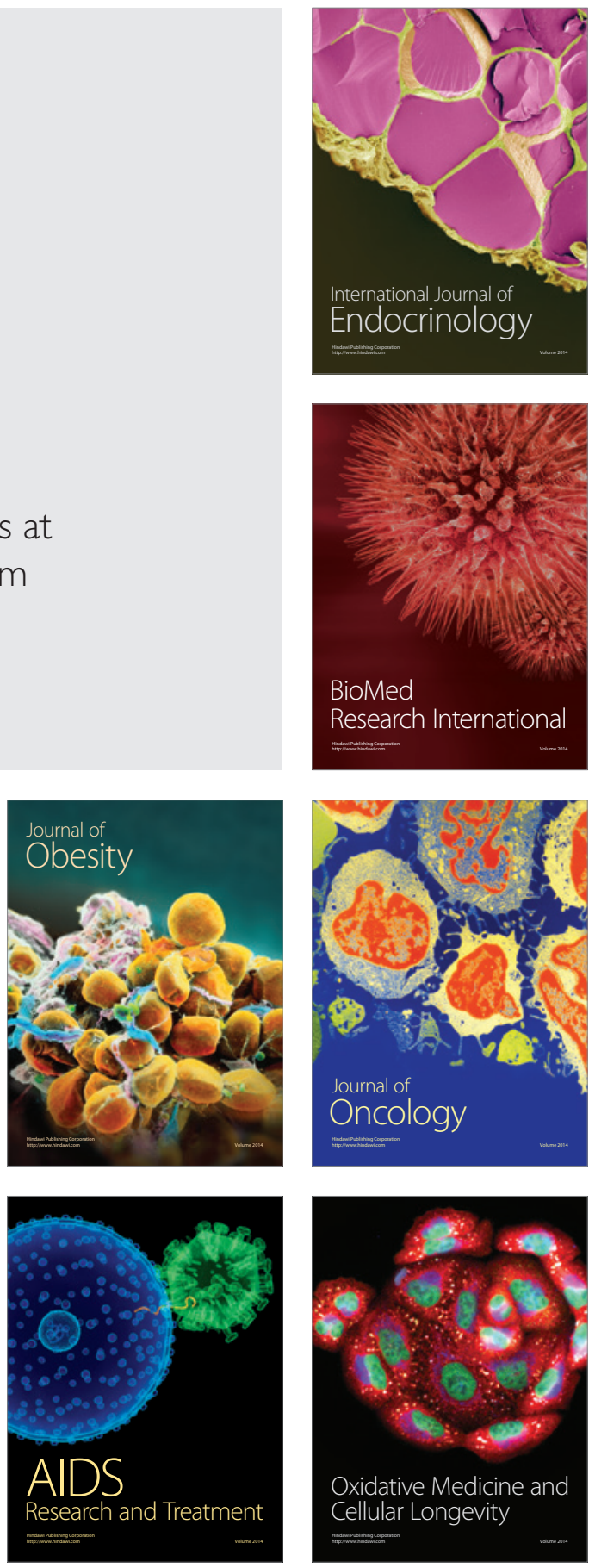